
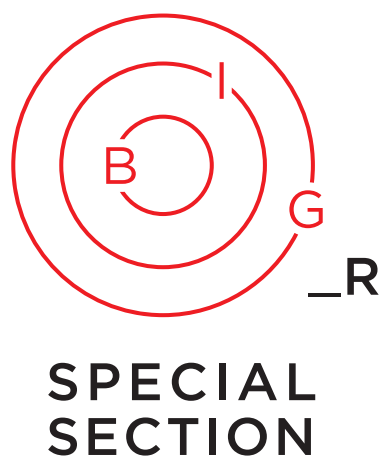

\title{
Introduction: Comparing and Contrasting EU Border and Migration Policy - Are They Exemplary?
}

\section{Emmanuel Brunet-Jailly ${ }^{i}$ and Birte Wassenberg ii}

\begin{abstract}
This special section (thanks to the Jean Monnet Network, a European Union Erasmus+ Grant*) explores the impact of migration crises on European borders, internal and external, from a variety of disciplinary backgrounds. The following articles adopt comparative, historical, legal, sociological, and discursive approaches in order to confront questions arising from the 2015 Schengen and Dublin political crises, which seem to have put an end to the ideal of a "Europe without borders".
\end{abstract}

In Europe, the 2015 refugee crisis, resulting from unexpected increases in immigration across the Mediterranean Sea into the European Union (EU), has led to a re-questioning of not only the functions of borders in controlling migration, but also of European Integration. The ideal of a "Europe without borders" was questioned because both the Schengen agreement and Dublin convention were unable to deal with what turned out to be one of the major humanitarian challenges for Europe since the end of the Second World War. It forced Europeans to face difficult past and present issues as political movements and discourses straddled a continuum from xenophobic ills to re-energized 21st century Union. What is undisputable is that no European member state or EU institution forecasted the rather sudden increased number of people moving across their borders. It revealed that the EU overall, and some of its member states, especially Germany and Sweden, had become international lands of opportunity for people in the Middle and Far East.
Until 2014, the number of economic migrants and war refugees seeking asylum in the EU had been relatively stable over the years. But in 2015, it increased tenfold in about 12 months: comparing July 2014 to July 2015, the number of registered entries into the EU increased from 6000 to 50,000. By July 2015, 350,000 people had crossed the EU borders. By the end of 2015, over 1 million refugees had been welcomed across the 28 member states of the EU: 800,000 in Germany and over 100,000 children in Sweden. Obviously, the precise numbers were much greater than what was generally reported because calculating the number of longterm migrants takes a few months. However, the big picture is available today thanks to Eurostat: From 2010 until 2014, the exact number of immigrants settling across all 28 member states of the EU was stable, at about 3.5 million each year. In 2015, the increase reached 4.1 million and by the end of 2016 it was 4.6 million (Eurosta 2020) and since then, the annual numbers have been stable but at that level.

i Emmanuel Brunet-Jailly, PhD, is Chief Editor of Borders in Globalization Review and Professor of Public Administration at the University of Victoria, Canada. Contact: ebrunetj@uvic.ca

ii Birte Wassenberg, PhD, is Professor in Contemporary History at the Institute for Political Studies (Sciences Po) of the University of Strasbourg. Contact: Birte.wassenberg@unistra.fr 
The country of origin of people entering the EU has become increasingly diverse. What was at stake was not just one but a number of humanitarian crises in a geopolitical context that was greater than the Syrian and Libyan civil wars and included Iraq, Sudan (Darfur), South Sudan, Eritrea and also Nigeria, Niger, Mauritania and Mali. People moved because their home countries and country of origin were economically and politically unstable and dangerous. In 2015, the top 15 countries of origin included Syria, Eritrea, Afghanistan, Morocco, Albania, Pakistan, India, Tunisia, Nigeria, Ukraine, Algeria, Serbia, Kosovo, Bangladesh and Somalia, thus creating informational (UNHCR 2017), linguistic (Translators Without Borders 2017) and security policy difficulties to reconcile identity with non-documented entries (EU 2015). Another important aspect is that, in parallel to this increase, the number of people entering without visas was also sharply on the increase, hence overwhelming both maritime and land border posts and causing a security conundrum. This contributed to higher volatility of the narratives in particular from nationalistic movements and to an entanglement of the migration and security narratives and their polarization in the European political discourses (Huysmans 2006; Guild 2009; Bourbeau 2011; Vietti \& Scribner 2013, Estevens 2018), especially in the United Kingdom, where the Brexit movement was led by the United Kingdom's Independence Party (UKIP) mainly on these issues (Farage 2015).

Clearly, one striking aspect of this humanitarian crisis was that its sheer size was unexpected. In the summer of 2015, the European Commission was renewed and the President of the European Commission, Jean Claude Juncker, had just been chosen by European Council members on June 24th and confirmed by the European Parliament on July 15th. The work program agreed upon by the EU member states focused on the issue of energy in particular because of ongoing issues regarding the EU's energy dependency on Russia. Migration was only one of Juncker's top ten priorities which were job creation, the digital integration, the Energy Union, the industrial base, the monetary union, trade with the US, more justice Union, a better immigration policy, a stronger presence globally, and a more democratic Union. The better immigration policy was mainly about addressing the illegality of Mediterranean crossings and asylum seekers estimated at 153,000 for the first five months of 2015-whereas, in reality, the total number was 350,000 and nearly one million by the end of 2015. Hence, at the time, the European Commission's top ten priorities did not oversee a forthcoming increased immigration by about 1 million people in one year into the Union (European Commission, State of the Union 2015).

Up front, European member states at the periphery of the EU struggled and were overwhelmed with health, humanitarian, and security concerns. Governments in Hungary, Slovakia, Romania, Greece, as well as the Czech Republic, Denmark, and the United Kingdom were dead-against welcoming more immigrants; government authorities struggled to implement EU standards to register new immigrants and often because of the sheer numbers of people on the move, border staff were also overwhelmed. In Hungary for instance, the military was brought in and the government built a 170-kilometer-long fence, and passed laws that made it a criminal act to cross the border or to help immigrants.

Also, the EU member states which were not on the front line but at the center of the Union, held peripheral member states to the agreed Dublin regulation to register incoming migrants (finger printing/asylum processing) despite sometimes vast differences in human and financial resources and capacities. Within weeks, while the European Commission was calling member states to implement quotas to share the humanitarian and financial costs of welcoming asylum seekers, internal borders inside the EU started to close. Governments bickered over quotas, referring to the terms of the Union's treaties, and member states progressively closed their borders, declaring states of emergency.

Obviously, this re-introduction of border controls by several EU member states symbolized a questioning of the ideal of a "Europe without borders": the "separation" function of the border seemed to have been re-asserted. Indeed, since the signature of the Schengen Agreement in 1985 and in particular with the ambitious project of the Single European Market in 1987, the internal abolition of border-checks on EU citizens, goods, and financial transfers had become one of the main objectives of European Integration.

Regarding the historical development of European Integration, "Europe without borders" has been an objective ever since establishing the European Coal and Steel Community in 1952, then extended in the European Economic Community (EEC) from 1957 onwards with the creation of the Common Market, i.e. a European market without tariffs and trade barriers. In 1985, the Schengen Agreement, first concluded by France, Germany and the Benelux States, was another push towards the idea of a "Europe without borders." It propelled the project of a Single European Market (SEM) with four areas of free movement: goods, services, capital, and people.

Thus from the mid-1980s and until the end of the century, European integration policies of de-bordering were in focus. The European Community implemented the ideal of "borderless Europe" by enhancing internal movements and cross-border policies. For instance, in 1985, the goal 
of then president of the European Commission, Jacques Delors, was the completion of "borderless Europe" by means of the SEM (COM/85/0310), which also included introducing procedural change on the Community's decision-making process. The Single European Act in 1986 enlarged the use of qualified majority vote and thus ensured much market integration of goods in the 1990s. This was also due to the EU's new competition policy and powerful Competition Directorate that worked at preventing anti-competitive corporate behaviours across the Union. These successful policies were then followed in early 2000 with a liberalization of the service sector.

Also, the European Commission supported the implementation of free circulation by increasing support to cross-border cooperation at the internal and external EU borders. The Interreg program policies expanded from one to 28 billion between the first and fifth programming periods in 2020 (INTERREG 202Oa) and whereas the initial programs focused on cross-border infrastructures (2O2Ob), the following periods emphasized increasingly the objective of a "borderless Europe" in terms of territorial cohesion in border regions (INTERREG 2020c). With the development of the Interreg program, cross-border cooperation gradually became a tool for the EU to reach the ideal of "borderless Europe"-at least internally.

The management of external borders was predominantly understood as managing migration. But, it was not an issue of concern until 2015 even in border regions (Interact 2017), where the awareness and knowledge of the border as a boundary line and an obstacle to free movement had always existed. Initially, migration was not considered aa potential threat to the implementation of good trading and neighbourhood relations in and across the EU. Indeed, the goals were to overcome borders as "a scar of history" and that was the main incentive to start cross-border cooperation for many border regions. However, paradoxically, it seems that the more cross-border cooperation developed, the greater the awareness regarding the persistence of the borders in border regions and the perceptions that borders do divide the $\mathrm{EU}$, that the Union is regionally and nationally diverse (Medeiros 2015, Cojanu and Robu 2014; Ciok and Racyk 2008; Leibenath and Knippschild 2005). Also, after the integration of the Schengen Agreement into the EU Amsterdam Treaty in 1997, external problems of border management progressively became more apparent: refugees and migrant management (and mis-management) led to increasing difficulties in cross-border relations across the internal and external borders of the EU. The Schengen border "Calais-Jungle" camp between France and the United Kingdom is an illustration of such border management problems (Freedman 2018). This reality led to further investments in the EU's neighbourhood policies (Barslund 2019).

However, the advent of the 2015 migration crisis spurred a general Schengen crisis. Following the uncontrolled massive inflow of migrants and refugees into the EU, several member states suspended the Schengen Agreement, which led to the impression that, due to the re-bordering which was taking place within the internal borders of the $\mathrm{EU}$, the ideal of 'borderlessness' had come to a historical end (European Parliament 2016).

Facing the 2015 crisis, the European Commission relied on two major policy tools: the Dublin Regulation and the Schengen Agreement. The Dublin Regulation of 2003 establishes which EU member state is responsible for asylum applications and the basic principle is that the first EU member state where a migrant or asylum seeker sets foot is responsible. The first-entry-point principle raises a very serious issue of financial and bureaucratic capacities for the EU's peripheral member states, in particular when those states are the poorest and newest members of the Union. EU member states such as Spain and Portugal for example had dealt with immigration issues since the early 1980s, but much more recent members such as Hungary or Romania did not have the staffing or equipment to manage a sudden increase immigration into their countries, and they were now on the front line. This well-known issue worsened in the summer 2015 when policy disparities, financial and bureaucratic capacities became unbearable for these external states. The first-entry-point principle is only manageable when the number of undocumented migrants is not in the thousands per day as was the case in the summer of 2015.

These tensions between EU member states had already been flagged in 2008 by the European Parliament. It had suggested in its report that "the Dublin system ... continues to be unfair both to asylum seekers and to certain member states" (UNHCR 2008) and, as noted by Morano-Foadi (2015), this imbalance of responsibility also affected the protection and implementation of human rights in the EU because it affected both the Court of Justice of the European Union and the European Court of Human Rights of the Council of Europe. Indeed, rights-standards of protection could not be met by member states, thus failing both on the counts of providing substantive justice and of fair asylum procedures across the EU. As noted by the European Parliament, this was particularly salient because asylum applications took months to process and applicants had to wait in facilities that in many cases did not uphold clear European and international standards of human decency and 
protection, in particular, along the east-European front and the borders with Turkey. Greece, Bulgaria, Romania and Hungary are known cases of deplorable humanitarian conditions for asylum seekers. However, Human Rights Watch, in its 2018 EU report, also singled out and criticized other EU member states. For instance, it criticized Croatia for pushing back migrants to Bosnia. It highlighted bad conditions in the camps of La Villette in Paris and of Grande-Synthe in northern France. It also denounced Germany for its deportation practices (and noted increased xenophobic demonstration and violence), Greece for hosting asylum seekers without protecting their rights to health and schooling, Hungary for criminalizing services, advice and support to migrants, Italy for handing over migrants to Libyan coast guards, and the Netherlands for refusing to confirm how many of its citizens had lost their citizenship due to terrorist activities. Poland was blamed of undermining human rights protection, Spain for using excessive violence to crack down and killing on migrants in Ceuta. Finally, the United Kingdom was cited for complicity with $\mathrm{ClA}$-led torture and secret detention. However, the report also praised the EU for promoting human rights globally and for working with neighbouring states, but it noted as well that the EU's agreements with Turkey, Libya, Egypt and Sudan meant that it was "mute" on human rights violations in those countries (Human Right Watch 2019).

Nevertheless, the EU's response to the migration crisis was to mobilize large resources to increase the policy capacity of member states, neighbourhood states, and of the competent EU agencies (EC Annual Report 2018). On the issue of migration, the Asylum, Migration and Integration Fund (AMIF) focusing on increased solidarity and on the management of migration increased to 3.137 billion euros (AMIF 2020). It enhanced specific actions such as the External Border Fund, the European Return Fund, the European Refugee Fund and the European Fund for Integration of third Country Nationals. Also, a 3.8 billion boost went to the Internal Security Fund (ISF-Border, Visa, 2020) for borders, visa and police cooperation to strengthen internal security, law enforcement cooperation, and the management of the external borders of the EU. Hence, the ongoing debate about Fortress Europe may be a reality in particular because the primary goals of EU border and security policies are about stopping migrants from entering the EU. Indeed, neighbourhood countries (such as Turkey and Libya, but also Morocco, Lebanon, Jordan) seem to be turned into "destination" countries as they host migrants long term in their workforce or in camps. And also, there are striking examples of informal policy agreements between the EU and neighbourhood countries whereby migrants can be pushed back and forth across the Schengen borders at EU member states' will (Triandafylildou 2013; Cassarino 2010, 2007; Geddes 2005). Last but not least, the number of orders to leave the EU have increased dramatically to 500,000 per year since 2015 (EC Annual Report 2018, 70).

In this special section, we ask whether the specific 2015-16 political and policy responses to increased migration in Europe are permanent and how they affect EU integration and the ideal of the 'borderless Europe' and its corollary, 'Fortress Europe'? What are the consequences for migrants' rights in the EU, for Schengen borders, and for EU cooperation? And what were the impacts on cross-border relations and cooperation? Last but not least, we review the politics and policy narratives that framed the contexts of those policy answers, asking whether they are permanent or temporary measures to the migration crisis.

In the first of five articles, historian Birte Wassenberg deals with the "myth" of a borderless Europe in European Integration history. Wassenberg suggests that the Schengen crisis, spurred by the migration wave across the Mediterranean Sea in 2015, has led to a re-questioning of the ideal of a "Europe without borders". She suggests and demonstrates that there is a difference in the concept of a "Europe without borders" in terms of free movement of goods, services, capital, and, people, on the one hand, and, on the other, the constructed "myth" of a "Europe without borders" where all borders of the EU are assumed to have negative functions and should therefore disappear. The Schengen crisis helps to unravel this "myth" by demonstrating that borders can also have positive functions, that they persist within the EU and that their control remains a competence of EU member states. Wassenberg shows that the re-introduction of border controls has not put an end to a "Borderless Europe" in terms of free circulation of capital, services and goods, which has not been interrupted. Even when looking at the free movement of people, from legal perspective, the temporary suspension of the Schengen convention was authorized and the checks at the border only signified a delay and not a disruption of the possibility of cfrossing the border. However, the Schengen crisis has ended the "myth" of a "Europe without borders" and "borderlessness" as construed since the mid-1980s under the influence of the European Parliament and the European Commission, which suggests that it actually means the abolition of political borders and the creation of a European Federation. This "myth" had turned the ideal of a "Europe without borders" into the final objective of European integration and it might have become an end in itself. Adopting a less mystified perspective on "Europe without borders" helps to better explain the processes of de- and re-bordering in Europe and its relationship 
with European integration. By adopting a less unidimensional concept of borders regarded only as "negative" barriers the article helps to understand why most borders-i.e. political, administrative, cultural, territorial-have not disappeared and why border controls may be reintroduced by EU member states. Wassenberg therefore illustrates that a "Europe without borders" as a generalized all-englobing phenomenon has never existed and that not only de-bordering but also re-bordering continues to exist within the EU.

In the second article, Anja Bartel, Catherine Delcroix, and Elise Pape look at the Dublin convention from a sociological point of view. They remind of the original intent of the convention: it is based on the principle that the first member state in which an asylum seeker enters and where finger prints are stored is responsible for the person's asylum procedure. Especially since the increased number of asylum seekers in Europe in 2015 , this regulation has been more and more criticized: on the one hand, it increases pressure on the external border regions of the EU, where most asylum seekers enter and that are at the same time often the least able to ensure their social protection. On the other hand, the asylum seekers themselves are given no choice in determining the country in which they wish to live and plan their future. Despite the Dublin convention, however, a large number of asylum seekers have de facto lived in two or more European countries and have in some cases applied for asylum in more than one country. The chapter discusses the effects of EU regulations on individual and family lives but also the way individuals and families challenge EU legislation. It is based on the method of biographical policy evaluation which, rather than assessing policies through top-down approaches, evaluates them in the light of individuals' experiences, thereby analyzing the detailed longitudinal effects of policies on life paths, but also strategies individuals employ to adapt to (or resist) these policies. Drawing on biographical interviews conducted with individuals and families seeking asylum who have lived in different EU member states and who are now based in Strasbourg, the article analyses the way different levels of policies interact in their lives: the European, national and communal levels, how these persons have managed to adapt to different European countries (for example by learning different European languages) and how living as a family as opposed to living alone has impacted this process. Interviews with professionals in the field of asylum are also referred to. In sum, the paper discusses how internal and external EU borders have impacted the refugees' lives and how refugees have challenged borders within Europe and the current regulatory system.

Frédérique Berrod assesses, from a legal point of view, the consequences of the Schengen crisis for the internal and external EU borders. The impact of the Schengen crisis on migrants is assessed both from a legal and a sociological perspective. Berrod hypothesizes that the EU was established on the ideal of a "Europe without borders", meaning the elimination of internal borders with a counterpart being the transfer of border controls to the EU's external borders. In the Schengen Area, external borders are controlled by common principles and procedures regulated by the Schengen Border Code. Member states negotiated the Schengen Agreement to maintain such border controls, to be able to protect their citizens from various dangers, and to guarantee their national migration policies towards third-country nationals (non-European), whereas cross-border cooperation has been developed to reinforce the security of the Schengen space of free movement. EU member states have therefore transposed the function of national border controls to the external EU borders. The migrant crisis has reinforced these external borders by a more systematic control of citizens to check their movements and to cross the available data centralized in EU databases. For this purpose, the member states have even accepted a European specialized body of controllers, the new Frontex. The Schengen Agreement has also resulted in a common security policy based on "open intelligent borders" and on the externalization of certain controls to so called 'hotspots' located either at the external EU borders or even in third countries. Berrod examines such policies also from the point of view of the respect of human rights: is it possible to control citizens at the borders and at the same time to guarantee an effective respect of human rights? What is the purpose of cross-border cooperation in this context? The question of the reallocation of migrants within the EU, based on the principle of solidarity between member states is also addressed. The Schengen crisis is in fact constituted, from a legal perspective, by the political will of certain EU member states to bring back systematic controls of their citizen and migrants. Thus, there is a new focus on national borders, because the member states are not confident and perceive vulnerabilities in the common control of external EU borders. The Schengen Border Code was adapted to guarantee such national decisions to re-establish controls at national borders but also to avoid any unilateral decision. The risk of the return of national borders within the EU is therefore assessed by Berrod in the context of the difficulty of maintaining proportionate and provisional national border checks. The analysis is concentrated on the point of the governance of Schengen exceptions: is it possible to organize a common EU governance of these national decisions? The question of the necessary cooperation of EU member states with the new Frontex is also addressed to understand to what extent it means-or not-a crisis of crossborder cooperation. 
Also from a legal perspective, Aude Bouveresse demonstrates that inside the territory of the $\mathrm{EU}$, borders are necessary and problematic at same time. Indeed, while the functioning of the internal market is essentially based on the freedom of movement and implies the elimination of borders as barriers to trade, the problem is that the freedom of movement of the European citizen also remains embedded in this conceptual framework of borders. This is due to the fact that the EU's competences remain limited in the social field concerning the management of the internal market on the one hand and that the concept of European citizenship remains largely dependent on nationality, which cannot be considered outside national borders, on the other hand. In other words, nationality determines the status of European citizen and the rights deriving from it. Bouveresse gives an analysis of the EU's case law on this dialectic relationship between borders and citizenship. The European Courts' approach seems ambivalent since it conditions access to European citizenship and has to combat all forms of discrimination on grounds of nationality which hinder the establishment and functioning of the internal market, but also has to allow member states to maintain a special relationship with their nationals. Thus the application of the EU treaties requires the nationality criterion underlying European citizenship to be taken into account and protected, just as the exercise of freedom of movement requires combating the nationality criterion, and both pursue the same objective of advancing European integration. However, Bouveresse shows that when the Court legitimizes the nationality criterion in support of a differentiation of European citizens, it creates in fact new borders, i.e. between nationals and non-nationals. By revalorizing nationality in this way, the European Court of Justice runs the risk of slowing down the integration process or even calling into question its model by running the risk of a renationalisation of the individual and raising new frontiers.

Finally, Claude Beaupre and Franziska Fischer examine the narratives and discourses of the 2015 refugee crisis and their impact on border security in France and Germany. Their assumption is that what truly made the refugee and migrant crisis such a phenomenon was not the sheer number of individuals making their way to Europe, nor the seemingly ceaseless casualty reports it generated, but first and foremost the context in which it developed. Already in 2015, sensitivities towards foreigners were heightened in most of Europe. By then, the continent was attending to the complexities of the increasing frequency of Islamist-linked terrorist attacks since 2006, the 2008 financial crisis, the Greek debt crisis of 2010, the Crimea/Ukraine crisis of 2014, and the increasing support for right-wing, nativist political parties agitating EU politics. The culmination of this led many European states to adopt temporary border controls along their internal borders. For some, this tendency towards more borders has become a new status quo from which two trends have been identified: controlling the movements of refugees and migrants (exemplified by Germany) and countering terrorist threats (exemplified by France). In both cases, dubious representations have created a change in the discourse of the label 'refugee' which now not primarily sparks fear, disdain, and rejection from the public, and also fails to differentiate between the multiple identities and legal-entities that enter Europe. As such, the frequent portrayal of these refugees as security threats makes border security a tool with which to regain control over this perceived threat. In the end, this contribution helps us understand some of the elements which have led France and Germany to perceive the events of 2015/2016 as a danger to national security. By briefly outlining the historical development in both countries and their respective shift in perception of the label 'refugee,' Beaupre and Fischer aim to present the different factors which led them to take on the same course of action: reintroducing border controls.

\section{Note}

* The European Commission's support for the production of this publication does not constitute an endorsement of the contents, which reflect the views only of the authors, and the Commission cannot be held responsible for any use which may be made of the information contained therein.

\section{Works Cited}

AMIF, 2020. Migration and Home Affairs, Asylum, Migration and Integration Fund. https://ec.europa.eu/home-affairs/financing/fundings/migration-asylum-borders/ asylum-migration-integration-fund_en

Barslund, Mikkel, Matthias Lucke, and Martin Ruhs. 2019. Rethinking EU Migration and Asylum Policies: Managing Immigration Jointly with Countries of Origin and Transition. CEPS-MEDAM Assessment Report. https://www. ceps.eu/wp-content/uploads/2019/10/MEDAM-assessment-report-2019.pdf

Bourbeau P. 2011. The Securitization of Migration: A Study of Movement and Order. Abingdon: Routledge.

Cassarino, Jean Pierre. 2007. "Informalising Readmission Agreements in the EU Neighborhood". Italian Journal of International Affairs 42(2): 179-196. https://doi. org/10.1080/03932720701406365

Cassarino, Jean Pierre. 2010. "Unbalanced Reciprocities: Cooperation on Readmission in the Euro-Mediterranean Area". The Middle East Institute, Special Edition, Viewpoints, Washington DC. https://dx.doi.org/10.2139/ssrn.1730633

Ciok S., and A. Raczyk. 2008. "Implementation of the EU Community Initiative INTERREG III A at the Polish-German border An attempt at evaluation" in Markus Leibenath, Ewa Korcelli-Olejniczak, and Robert Knippschild (eds) Crossborder Governance and Sustainable Spatial Development. Springer, Berlin, Heidelberg. https://doi.org/10.1007/9783-540-79244-4_3 
Cojanu, Valentin, and Raluca Robu. 2014. "An Evaluation of InstitutionalStrengthofCross-borderCooperationStructures". Editura Universitatii Alexandru loan Cuza din lasi. https://www.ceeol.com/search/article-detail?id=598189

Esteven, Joao. 2018. "Migration Crisis in the EU: Developing a Framework for Analysis of National Security and Defence Strategies", Comparative Migration Studies 6(28): 1-21. https://doi.org/10.1186/s40878-018-0093-3

European Commission. 2018. Annual Report on Migration and Asylum. https://ec.europa.eu/home-affairs/sites/ homeaffairs/files/docs/pages/00_arm2018_synthesis_ report_final_en.pdf

European Parliament. 2016. Internal Border Controls in the Schengen Area: Is Schengen Crisis-proof? Directorate-General for Internal Policies, Policy Department C - Citizens' Rights and Constitutional Affairs. Study of the LIBE committee. https://www. europarl.europa.eu/RegData/etudes/STUD/2016/571356/ IPOL_STU\%282016\%29571356_EN.pdf

European Union. 2015. Refugee Crisis: European Commission takes decisive action - Question and answers. September 19, 2015. https://ec.europa.eu/commission/ presscorner/detail/en/MEMO_15_5597

European Union. 2017. Trade Policy Review, Report by the European Union. https://trade.ec.europa.eu/doclib/ docs/2017/july/tradoc_155734.pdf

European Union. 2018. A Study of the Communication Channels Used by Migrants and Asylum Seekers in Italy, with a Particular Focus on Online and Social Media. Publication Office of the EU, Directorate General of Migration and Home Affairs. https://op.europa.eu/en/ publication-detail/-/publication/2af2973d-48fc-11e8-be1dO1aa75ed71a1/language-en/format-PDF/source-69700790

EU - INTERact. 2017. Interreg responses to migration challenges. (July,) Interact-eu. http://www.interact-eu.net

EU INTERREG. 2020a. European Territorial Co-operation. https://ec.europa.eu/regional_policy/en/policy/cooperation/european-territorial/

EU INTERREG. 2020b. European Territorial Co-operation. https://ec.europa.eu/regional_policy/en/policy/cooperation/european-territorial/interregional/

EU INTERREG. 2020c. European Territorial Co-operation. https://ec.europa.eu/regional_policy/en/information/ publications/communications/2017/boosting-growthand-cohesion-in-eu-border-regions

Eurostat. 2020. Immigration, Persons: Total number of long-term immigrants arriving into the reporting country during the reference year. https://ec.europa. eu/eurostat/tgm/table. do?tab=table\&init=1\&language $=$ en\&pcode $=$ tps00176\&plugin $=1$

Farage, Nigel. 2015. "Migrant numbers creating 'security crisis"”, BBC, July 30. https://www.bbc.com/news/av/ uk-politics-33714279/ukip-s-nigel-farage-migrant-numbers-creating-security-crisis
Freedman, Jane. 2018. “'After Calais': Creating and Managing (In)Security for Refugees in Europe". French Politics 16: 400-418. https://doi.org/10.1057/s41253-018-0071-z

Geddes, Andrew. 2005. "Europe's Border Relationship and International Migration Relations". Journal of Common Market Studies 43(4): 787-806. https://doi.org/10.1111/ j.1468-5965.2005.00596.x

Guild E. 2009. Security and Migration in the 21st Century. Cambridge: Polity.

Human Right Watch. 2019. World Report: European Union Events of 2018. https://www.hrw.org/world-report/2019/country-chapters/european-union

Huysmans J. 1995. "Migrants as a Security Problem: Dangers of 'Securitizing' Societal Issues" in R. Miles and D. Thranhardt (eds) Migration and European integration: The Dynamics of Inclusion and Exclusion. London: Pinter Publishers: 53-72.

ISF-Border, Visa. 2020. Internal Security Fund - Border and Visa. Justice and Home Affairs. https://ec.europa.eu/ home-affairs/financing/fundings/security-and-safeguarding-liberties/internal-security-fund-borders_en

Leibenath, Markus, and Robert Knippschild. 2005. "Systemic Evaluation of Cross-border Networks of Actors: Experience with a German Polish Czech Cooperation Project”. Journal of Borderlands Studies 20(1): 73-90. https://doi.org/10.1080/08865655.2005.9695635

Medeiros, Eduardo. 2015. "Territorial Impact Assessment and Cross-border cooperation". Regional Studies, Regional Science 2(1): 97-115. https://doi.org/10.1080/ 21681376.2014.999108

Vietti F, and T. Scribner. 2013. "Human Insecurity: Understanding International Migration from a Human Security Perspective", Journal on Migration and Human Security 1(1): 17-31. https://doi.org/10.1177/233150241300100102

Morano Foadi, Sonia, and Lucy Vickers. 2015. Fundamental Rights in the EU. A Matter for Two Courts. Oxford and Portland, Oregon, USA: Hart.

Triandafyllidou, Anna. 2013. Circular Migration Between Europe and its Neighborhood: Choice or Necessity? Oxford University Press.

Translators Without Borders and Mixed Migration Platform. 2017. Putting Language on the Map in the European Refugee Response, Research Report. https://translatorswithoutborders.org/wp-content/ uploads/2017/04/Putting-language-on-the-map.pdf

UNHCR. 2008. The Dublin Regulation, Asylum Europe, Now That is Up to You. www.unhcr.org/4a9d13d59.pdf

UNHCR. 2017. Innovation Service Increasing Two-way Communication with Refugees on the Move in Europe. https://www.unhcr.org/innovation/increasing-twoway-communication-with-refugees-on-the-move-ineurope/ 